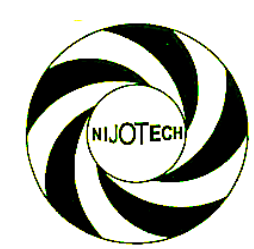

Nigerian Journal of Technology (NIJOTECH)

Vol. 37, No. 4, October 2018, pp. 1141 - 1146

Copyright@ Faculty of Engineering, University of Nigeria, Nsukka,

Print ISSN: 0331-8443, Electronic ISSN: 2467-8821

www.nijotech.com

http://dx.doi.org/10.4314/njt.v37i4.38

\title{
COMPARATIVE ANALYSIS OF CALORIFIC VALUES OF SELECTED AGRICULTURAL WASTES
}

\author{
J. O. Awulu' , P. A. Omale",* and J. A. Ameh ${ }^{3}$

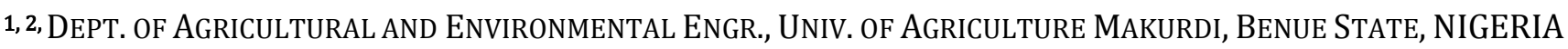 \\ 3, Mechanical Department, University of Agriculture MaKuRdi, BenUe State, NIGERIA \\ E-mail addresses:1 jawulu@yahoo.com, 2ayeslody4all@gmail.com, 3joamagada6@gmail.com
}

\begin{abstract}
Energy used for domestic application are expensive and beyond the reach of the rural poor. An alternative energy source is therefore a welcome development. This research work was aimed at determining the calorific values of Corn cob, Rice husk and Sawdust agricultural wastes materials. Standard method of calorific value determination involving the use of Bomb Calorimeter was adopted. From the investigation, the calorific value of Rice husk, Sawdust and Corn cob are $2938.86 \mathrm{Kcal} / \mathrm{kg}, 3155.30 \mathrm{Kcal} / \mathrm{kg}$ and $3227.78 \mathrm{Kcal} / \mathrm{kg}$ respectively. The agricultural materials were further subjected to briquetting and the calorific values determined to be $2092.48 \mathrm{Kcal} / \mathrm{kg}, 2379.76 \mathrm{Kcal} / \mathrm{kg}$ and 2923.36Kcal.kg for Rice husk, Sawdust and Corn cob briquettes respectively. The agricultural wastes met the minimum standard calorific value which range from $1500 \mathrm{cal} / \mathrm{kg}-1670 \mathrm{Kcal} / \mathrm{kg}$. The selected wastes have calorific values in the following decreasing order: Corn cob > Sawdust> Rice husk; and the corresponding briquettes is in the order: Corn cob >Sawdust >Rice husk. The selected wastes however, have lesser calorific values when briquetted. If agricultural wastes are used in place of firewood, this development will minimize deforestation which leads to desert encroachment and soil degradation.
\end{abstract}

Keywords: Agricultural waste, calorifuc value, corn cob, Rice husk and saw dust

\section{INTRODUCTION}

Fuel consumption represents a measure of nation's index of development and improved standard of living. As a nation develops industrially, individuals own cars, generating plants, other forms of mechanical devices which operate using one form of fuel or the other. As a result of this, there's an increase in the utilization and demand for fuel for industrial and domestic purposes. This energy is mostly gotten from crude oil and a lesser extent coal and natural gas. Other energy sources usually not tapped and utilized are tar sand, nuclear and biomass [1]. The energy utilization of Nigeria is characterized by the use of fossil fuel and fuel wood for wide range of applications from cooking, lighting to providing power for industrial utilization. However, only four energy sources are currently being utilized in processed form; these are coal, crude oil, natural gas and hydropower [2]; the remaining energy sources are either not developed fully or completely ignored.

However, for applications like cooking, heating, lighting and so on, the types of fuels mostly used are kerosene, gas, electricity, wood and coal. Apart from wood and coal, other sources of energy are no longer easily used by the poor populace because of cost and nonavailability.

Between 1970 and 1980; natural gas accounts for only $31 \%$ of total commercial energy consumption; coal accounts for only less than $1 \%$ for use in households and small scale industries; fuel, wood and charcoal accounts for over $51 \%$ of total energy consumed in Nigeria and recent estimates range between 51- 88 million $\mathrm{m}^{3}$ [3]. The present pattern and changes in energy use in Nigeria indicates that more intensive exploitation of various energy use is required to cope with the future demand for energy, as the conventional energy source reserve is depleting at an increasing rate. One of the more promising energy sources with an overwhelming potential and environmentally friendly is the "Biomass". Biomass is a non- conventional, renewable energy obtained from mainly organic matters storage of images (Solar) and materials in complex organic substances primarily by gross photosynthesis [4].

Biomass has been the principal source of food, energy

* Corresponding author, tel: +234-803-863-7463 
and materials for man since early time. It still provides practically all food, except salt and a few minerals, and it is applied commercially in energy generation in fire places and wood stoves, wood and waste boilers, biogases and sugar cane plantations etc. [5]. Biomass fuels, however, are available almost everywhere on earth; often relatively cheap, virtually inexhaustible and when properly managed, renewable and environmentally friendly; this situation is expected to continue into the foreseeable future.

In Northeast Brazil, existing sugar cane residue and future potential production of wood on dedicated plantations could be used to generate annually up to 41 TWh and 1400 TWh of electricity compared with present annual generation of 30TWh [6].

Nearly $15 \%$ of the world's fuel supplies are from biomass which is mainly fuel [7]. Estimates have placed a total annual consumption of wood in Nigeria at about 50-55 million $\mathrm{m}^{3}$ of which about $90 \%$ is for fire wood [8]. Annual deforestation of the woodlands in the Northern Nigeria is to the tune of 92,000 hectares; the extraction of fuel wood in Nigeria has been estimated at about 3.85 times the rate of re-growth and almost ten times the rate of regeneration [6].

However, the undesirable effect of felling trees for domestic energy supply that is of serious concern to energy researchers are the ever rising price of fuel wood, soil erosion, deforestation and desert encroachment. Loss of forest cover is a serious problem around the world, particularly in developing countries. In some of these countries, forest cover has decreased from over $60 \%$ in just a few decades [9].

Applications of biomass residue are summarized as follows; fuel, fodder, fiber, feedstock and further uses (e.g. conditioning of soil, straw for mush room growing and parking materials). Some even have simple purpose; for example, rice husk can be burnt as fuel and the ashes used by steel industry as insulator and source of carbon [10]. Charcoal, saw dust, rice husk, corn cob, and other agricultural residues as fuel will give a high calorific value and has the tendency to conserve heat for a long time. The utilization of these wood alternatives as fuel could be highly promising as alternative energy for cooking and heating. Large amount of saw dust, rice husk, charcoal, corn cob and other agricultural residues are laying waste in many timber shades, rice mills, household etc. It has been a common practice by most sawmills and rice mills to bum and/or dispose their sawdust and rice husk instead of using them effectively [11].

There is a need to reduce the over dependence on kerosene, cooking gas and fire wood as a source of energy for cooking, drying and for other agricultural applications that require the supply of heat. There is however justifications in carrying out the comparative analysis of calorific values of some selected agricultural wastes due to large annual turn up of these agricultural wastes, which if properly harnessed can produce useful heat energy.

One of the most efficient ways of converting bulk biomass residues to fuel, which when burnt produces appreciable heat is through briquette. It involves the collection of biomass materials that are not usable as such because of their low density and compressing them into a solid fuel product of any convenient shape that can be burnt like wood, thus the material is compressed to form a product of higher bulk density, lower moisture content and uniform size, shape and material properties. Briquettes are easier to package and store, cheaper to transport, more convenient to use, and their burning characteristics are better than those of the original material [12].

The objective of this research work was to compare the calorific values of selected agricultural wastes and ascertain their suitability for energy production. It is however, necessary to know the calorific values of agricultural wastes or biomass residues intended to be used for energy production to enable designers obtain the heat energy output of the various wastes for application in different areas of interest.

\section{MATERIALS AND METHOD}

\subsection{Preparation of Briquettes}

The rice husk, sawdust and corn cob were obtained from available sources.' Rice husk, sawdust and part of the corn cob were separately dried to $0.87 \%, 6.45 \%$ and $4.1 \%$ moisture contents respectively, crushgrinded and sieved through an 850 micrometer sieve. A metallic cylindrical mould was constructed, starched powder obtained and prepared into gummy liquid using boiling water.

Preparation of briquette involves the compression of waste materials into solid fuel products of any required shape and size that can be burnt like wood or charcoal. The equipment required for producing briquettes consist of a drier, a press, an extruder with a tapered screw and a large revolving disk. However, due to the unavailability of some parts of this equipment and the financial potential of the briquettes produced, a mould, a pestle and open air drying method was adopted.

The sample material must bind during compression; otherwise, when the briquettes are removed from the mould, it will crumble. To improve cohesion, 6\% starch was mixed with each sample separately-sawdust first, 
then rice husk and finally corn cob. The sticky material was separately charged into the mould and compressed using pestle; the briquettes was gently pushed out of the mould and thoroughly oven dried at $100^{\circ} \mathrm{C}$. Two replicates of each sample-rice husk, sawdust and corn cob were produced.

\subsection{Determination of Calorific Values}

The determination of the calorific value of a solid/liquid fuel is a typical test situation where the results are meaningless unless the test is carried out using the proper equipment developed for the job and the specific procedure properly followed.

\subsection{Calorimeter Method}

One sample each of 1 gram of rice husk, corn cob, and sawdust and their corresponding briquette were collected. Each of these samples was put in a pan, weighed and oven-dried for 24 hours at a temperature of $130^{\circ} \mathrm{C}$.

The moisture content of the sample was determined using the gallenkamp oven; model P165.

1. The moisture content (M.C.) of the sample was computed using equation 1.

$$
\text { M. } C=\frac{\text { Initial Weight }- \text { Final Weight }}{\text { Initial Weight }} \quad \times 100 \%
$$

The calorific values of the fuel samples were determined using the Parr oxygen Bomb-Adiabatic calorimeter; model 1341. The calorific values were determined by weighing one gram of each fuel sample; rice husk first, and transferred to the capsule; making sure the interior of the bomb including the support and crucible are properly cleaned and dried. A $10 \mathrm{~cm}$ long fuse wire was fixed to the two electrodes and the capsule containing the sample was carefully fixed into the electrode seat inside the bomb. The bomb head or cover was carefully and tightly closed using a special vice and spanner and then connected to the oxygen cylinder at a pressure of 30psi (207 Kpa) The calorimeter bucket was filled with 2 liters of distilled water. The bomb was carefully transferred into the bucket and ignition wires were pushed into the terminal socket on the bomb head; making sure no water is removed from the bucket with the fingers.

The calorimeter jacket was covered with thermometer facing down ward. The stirrer was turned by hand to make sure it runs freely without touching the calorimeter jacket or the bucket, the drive belt was then slipped into the pulleys and the motor was started. The stirrer was allowed to run for 5 minutes to reach equilibrium before any measured run. The temperature was read and recorded at one minute interval for 5 minutes; at the end of the 6th minutes, the calorimeter bomb was fired by pressing the ignition button and holding it down until the indicator light goes out. The bucket temperature started rising rapidly during the first few minutes, then becomes slower as the temperature approaches a stable maximum. After the final temperature reading; the motor was stopped, the drive belt removed and the calorimeter cover lifted. The knurled knob on the bomb head was carefully and steadily opened to release the gas pressure before removing the cap. The interior of the bomb was then examined for evidence of incomplete combustion; the bomb was then cleaned and dried. The whole procedure was repeated three times and temperature readings were taken for each sample. The mean time temperature readings were found for each sample. The calorific values were computed using equation 2 ;

$$
\mathrm{H}=\frac{\mathrm{T} \times W_{c}}{W_{g s}}
$$

Where; $\mathrm{T}=$ corrected temperature rise, $\mathrm{W}_{\mathrm{c}}=$ Energy equivalent of the calorimeter which is $2416 \mathrm{cal}$ and $\mathrm{W}_{\mathrm{gs}}$ $=$ Weight of samples used.

\section{RESULTS AND DISCUSSION}

The result of the variation of temperature with time for the samples are presented in Table 1, values of intercept and slope for the original and briquetted samples are shown on Table 2, while the values of temperature rise and corrected temperature for original and briquette samples are presented on Table 3 .

\begin{tabular}{|c|c|c|c|c|}
\hline \multirow{2}{*}{$\begin{array}{l}\text { Time } \\
\text { (mn) }\end{array}$} & \multicolumn{4}{|c|}{ Average Temperature $\left({ }^{\circ} \mathrm{C}\right)$} \\
\hline & Rice Husk Powder & Sawdust Powder & Corn cob & \\
\hline 0 & 24.66 & 25.91 & 25.33 & \\
\hline 1 & 24.68 & 25.92 & 25.34 & \\
\hline 2 & 24.70 & 25.94 & 25.36 & \\
\hline 3 & 24.71 & 25.96 & 25.36 & Pre-firing period (0-6 minutes) \\
\hline 4 & 24.72 & 25.96 & 25.38 & \\
\hline 5 & 24.74 & 25.98 & 25.39 & \\
\hline 6 & 24.78 & 25.98 & 25.39 & \\
\hline
\end{tabular}

Table 1: Variation of Temperature with Time for Rice Husk Powder, Sawdust Powder and Corn cob 


\begin{tabular}{ccccc}
\hline \multirow{2}{*}{$\begin{array}{c}\text { Time } \\
(\mathrm{mn})\end{array}$} & Rice Husk Powder & Sawdust Powder & Corn cob & \\
\cline { 2 - 5 } & 25.47 & 26.34 & 25.59 & \\
8 & 25.54 & 26.45 & 25.62 & \\
9 & 25.56 & 26.48 & 25.75 & \\
10 & 25.62 & 26.59 & 26.20 & \\
11 & 25.64 & 26.67 & 26.26 & \\
12 & 25.78 & 27.00 & 26.38 & \\
13 & 25.82 & 27.23 & 26.49 & \\
14 & 25.87 & 27.25 & 26.59 & \\
15 & 25.87 & 27.25 & 26.59 & \\
16 & - & - & 26.66 & \\
18 & - & - & 26.66 & \\
19 & - & - & 26.66 & \\
\hline
\end{tabular}

Table 2: Value of Intercept and slope for Original and Briquetted Samples

\begin{tabular}{lclccc}
\hline Sample & Intercept & Slope & T1 (Min) & T(Max) & T1 = Yc +273 \\
\hline Rice husk & 24.501 & 0.1012 & 6 & 15 & 297.501 \\
Briquette Rice husk & 28.465 & 0.0976 & 6 & 16 & 301.465 \\
Sawdust & 25.654 & 0.1038 & 6 & 15 & 298.654 \\
Briquette Sawdust & 27.528 & 0.0875 & 6 & 15 & 300.528 \\
Corn cob & 25.089 & 0.0954 & 6 & 18 & 298.089 \\
Briquette Corn cob & 27.048 & 0.0987 & 6 & 15 & 300.048 \\
\hline
\end{tabular}

Table 3: Values of Temperature Rise and Corrected Temperature for Original and Briquette Samples

\begin{tabular}{llllll}
\hline Sample & Initial Temp $\left({ }^{\circ} \mathrm{C}\right)$ & $\begin{array}{l}\text { Final Temp } \\
\left({ }^{\circ} \mathrm{C}\right)\end{array}$ & $\begin{array}{l}\text { Increased Temp } \\
\left({ }^{\circ} \mathrm{C}\right)\end{array}$ & $\begin{array}{l}\text { Correction } \\
\text { Factor }\end{array}$ & $\begin{array}{l}\text { Corrected } \\
\text { Temp }\left({ }^{\circ} \mathrm{C}\right)\end{array}$ \\
\hline Rice husk & 24.66 & 25.87 & 1.21 & 0.006 & 1.216 \\
Briquette Rice husk & 28.5 & 29.82 & 1.23 & 0.05 & 1.280 \\
Sawdust & 25.91 & 27.25 & 1.34 & 0.007 & 1.347 \\
Briquette Sawdust & 27.67 & 28.65 & 0.98 & 0.005 & 0.985 \\
Corn cob & 25.33 & 26.66 & 1.33 & 0.06 & 1.336 \\
Briquette Corn cob & 27.22 & 28.38 & 1.16 & 0.005 & 1.165 \\
\hline
\end{tabular}

The pre-firing period is the period during which the water in the inner vessel was gradually stirred for homogenous distribution of heat; it ranges from 0-6 minutes for each of the samples with mean temperatures rising from $24.66^{\circ} \mathrm{C}-24.78^{\circ} \mathrm{C}$ for rice husk; $25.91^{\circ} \mathrm{C}-25.98^{\circ} \mathrm{C}$ for sawdust and $25.33^{\circ} \mathrm{C}$ $25.39^{\circ} \mathrm{C}$ for corn cob. For the briquette samples, the mean temperature rise for rice husk is $28.59^{\circ} \mathrm{C}$ $28.76^{\circ} \mathrm{C}$, for sawdust is $27.6^{\circ} \mathrm{C}-27.73^{\circ} \mathrm{C}$ and corn cob rise from $27.22^{\circ} \mathrm{C}$ to $27.28^{\circ} \mathrm{C}$.

The firing period is the period the bomb was fixed and the temperature rose gradually until it reaches a constant value. The range of firing period for rice husk is 6-15min; for sawdust is $6-15 \mathrm{mins}$, and for corn cob is $6-18 \mathrm{mins}$; and the temperature rise from $24.78^{\circ} \mathrm{C}$ $25.8^{\circ} \mathrm{C}, 25.98^{\circ} 27.2^{\circ} \mathrm{C}$, and $25.39^{\circ} \mathrm{C}-26.66^{\circ} \mathrm{C}$ for rice husk, sawdust and corn cob respectively. The firing period for the briquette samples are as follow: 6$16 \mathrm{mins}, 6-15 \mathrm{~min}$, and 6-16mins for rice husk, sawdust and corn cob respectively; and the calculated temperature ranges from $28.76^{\circ} \mathrm{C}-29.82^{\circ} \mathrm{C} ; 27.73^{\circ} \mathrm{C}$ $28.65^{\circ} \mathrm{C}$ and $27.28^{\circ} \mathrm{C}$ for rice husk, sawdust and corn cob respectively.

Table 2 shows the values of slope intercept, minimum and maximum time for original and briquette materials. The slope and intercept for rice husk is 0.1012 and 24.501, sawdust is 0.1038 and 25.654, and corn cob is 0.0954 and 25.089 traced from the graph shown on figures 1, 2 and 3; with calorific values of 2938.8 $\mathrm{kcal} / \mathrm{kg}, 3155.30 \mathrm{kcal} / \mathrm{kg}$ and $3227.78 \mathrm{kcal} / \mathrm{kg}$ for rice husk, sawdust and corn cob respectively. Table 3 also depicts the values of slope and intercept for the briquette samples. The slope and intercept for rice husk is 0.0976 and 28.45, sawdust is 0.0875 and 27.528 and corn cob is 0.0987 and 27.048 respectively, giving calorific values of rice husk, sawdust and corn cob as $2092.48 \mathrm{kcal} / \mathrm{kg}, 2379.76 \mathrm{Kcal} / \mathrm{kg}$ and 2923.36 $\mathrm{Kca} 1 / \mathrm{Kg}$ accordingly. 


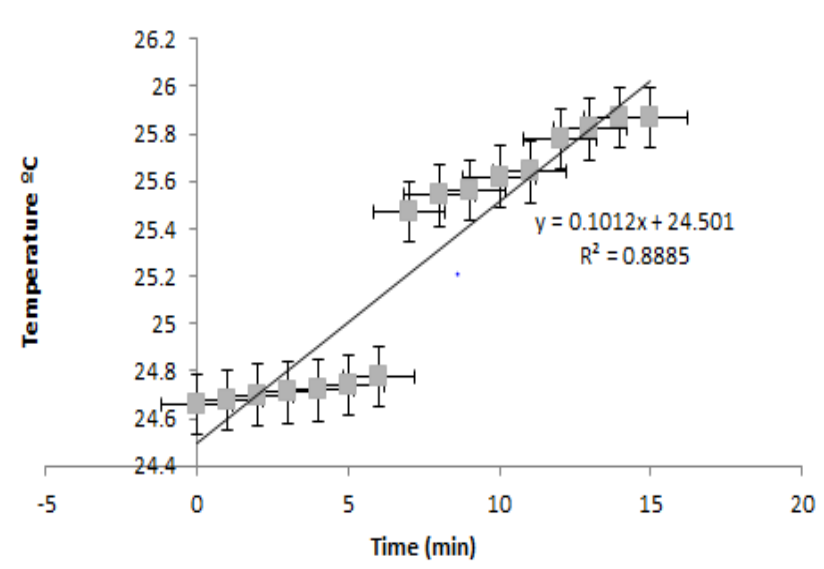

Fig. 1: Temperature-Time Graph for Original Rice Husk

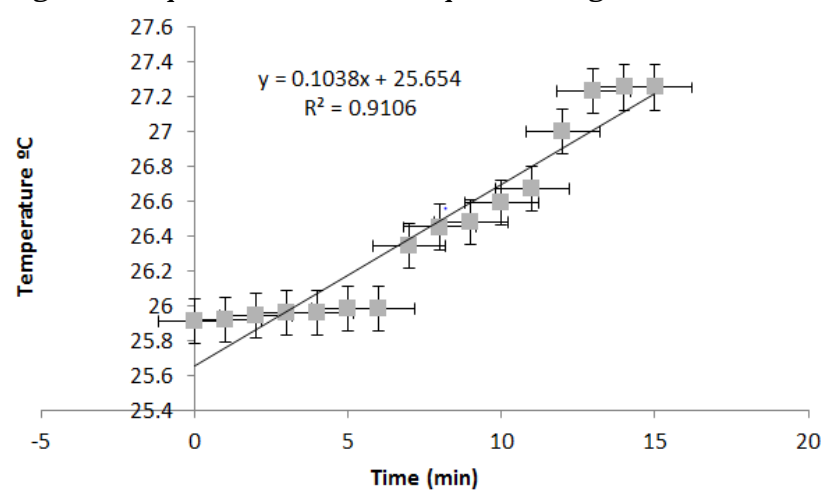

Fig. 2: Temperature-Time Graph for Original Sawdust Powder

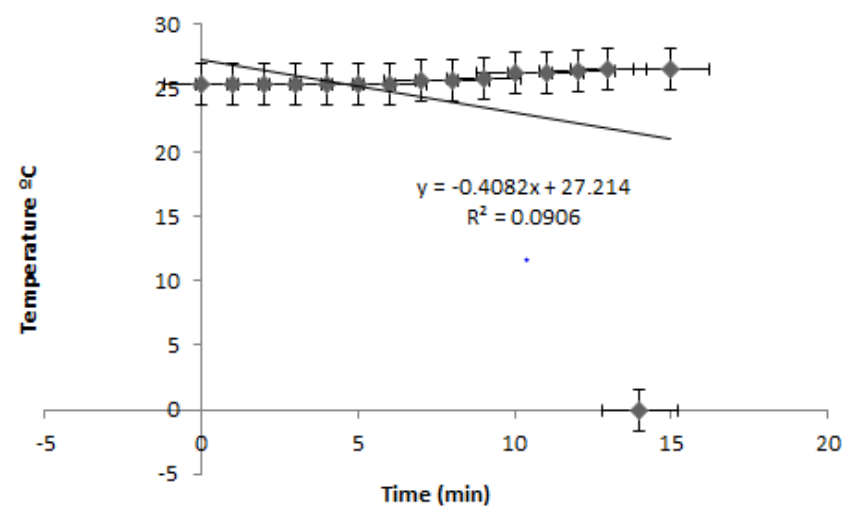

Fig.3: Temperature-Time Graph for Original Corn Cob

The calorific values of the original and briquette corn cob, rice husk and sawdust samples are shown on the composite bar chart shown on figure 4 .

The calorific values of briquette rice husk and sawdust exceeds that of the original materials. This agrees with the findings of [13] that the briquette material have greater calorific values than the original materials. The calorific values were obtained using the corrected temperature in the following order $3227.78 \mathrm{kcal} / \mathrm{kg}>$ $3155.30 \mathrm{kcal} / \mathrm{kg}>2938.86 \mathrm{kcal} / \mathrm{kg}$ for original corn cob, sawdust and rice husk respectively.

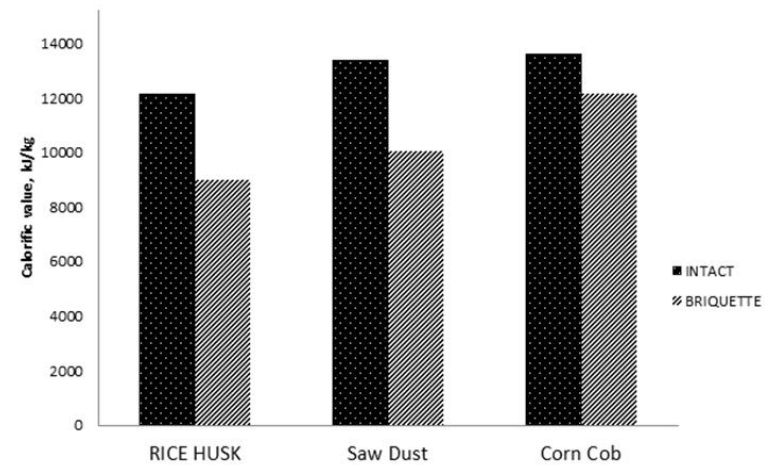

Fig. 4: Calorific Values of Original and Briquette of Selected Agricultural Wastes

Table 3 also shows the values of temperature rise and corrected temperatures for briquette rice husk, sawdust and corn cob. The temperature rise and corrected temperature for rice husk is $1.23^{\circ} \mathrm{C}$ and $1.280^{\circ} \mathrm{C}$; that of sawdust is $0.98^{\circ} \mathrm{C}$ and $0.985^{\circ} \mathrm{C}$; and that of corn cob is $1.16^{\circ} \mathrm{C}$ and $1.210^{\circ} \mathrm{C}$. The calorific values were determined in the following order: 2923.36kcallkg >2379.76kcallkg > 2092.48kcallkg for briquette corn cob, sawdust and rice husk respectively. The calorific values of the original materials exceed that of the briquette materials. This does not agree with the findings of [8] "the calorific value of briquette material is greater than that of the original material". This might largely be due to the moisture content, method of briquetting, type of binder used, standard condition of the bomb calorimeter and insufficient compressive force applied when briquette.

However, the calorific values determined in all cases for all the samples met the minimum standard requirement for heat energy generation - which ranges from $1500 \mathrm{kcal} / \mathrm{kg}-1670 \mathrm{kcal} / \mathrm{kg}$ according to [4].

\section{CONCLUSION}

It can be concluded from the results of experimental analysis that;

i. Original corn cob, saw dust and rice husk samples produced more heating value than their briquettes

ii. The range of calorific value of both the original and briquette corn cob, sawdust and rice husk samples are in the order of Corn cob $>$ Sawdust $>$ Rice husk

iii. The original calorific values of corn cob, sawdust and rice husk samples were 3227.78 $\mathrm{kcal} / \mathrm{kg}, 3155.30 \mathrm{kcal} / \mathrm{kg}$, and $2938.86 \mathrm{kcal} / \mathrm{kg}$ while the calorific values of briquette corn cob, sawdust and rice husk were $2923.36 \mathrm{kcal} / \mathrm{kg}$, $2379.76 \mathrm{kcal} / \mathrm{kg}$ and $2092.48 \mathrm{kcal} / \mathrm{kg}$ respectively which all met the minimum standard 
calorific value.

\section{REFERENCES}

[1] Gravalos, I., Kateris, D., Xyradakis, P., Gialamas, T., Loutridis, S.,Augousti, A., Georgiades, A.and Tsiropoulos, Z, A Study on Calorific Energy Values of Biomass Residue Pellets for Heating Purposes. Proceedings of the 43rd FORMEC Conference on Forest Engineering: Meeting the Needs of the Society and the Environment, Padova, 11-14 July 2010.

[2] Patel B., Gain B., Biomass characterization \& its uses as solid fuel for combustion, Iranica Journal of Energy \& Environment, Vol. 3 (2), pp123-128, 2012.

[3] Ioannis, G., Panagiotis, X.,Dimitrios, K.,Theodoros, G., Dimitrios, B., and Kyriakos, G., An Experimental Determination of Gross Calorific Value of Different Agroforestry Species and Bio Based Industry Residues, Natural Resources, 2016, 7, 57-68 2016

[4] Günther, B., Gebauer, K., Barkowski, W., Rosenthal, M. and Bues, C. T. CalorificValue of Selected Wood Species and Wood Products. European Journal of Wood and Wood Products, 70, 755-757. 2012.

[5] Weither, M, Saenger, E, Hartge, U., Ogada, T and Siagi, Z , "Combustion of Agricultural Residues" .Progress in Energy and Combustion Science. Vol. 26, 2000, pp.1-27, 2012.

[6] Singh, R. M., Kim, H., Kamide, M. and Sharma, T. "Biobriquettes an Alternative Fuel for Sustainable Development". Nepal Journal of Science and Technology. Volume 10, 2009, pp. 121-127. 2009.
[7] Kucha, E. I. Ameh,I. A and Awulu, I. O. "The Effect of Grate on the Performance of Improved Fuel Wood Stove". PeCop Journal of Science, Engineering and Technology, Vol. 1, Nos. 1 and 2, 2006.

[8] Sotelo Montes, C., Silva, D. A., Garcia, R. A., Muñiz, G.I.B. and Weber, J. C. Calorific Value of Prosopisafricana and Balanitesaegyptiaca Wood: Relationships with Tree Growth, Wood Density and Rainfall Gradients in the West African Sahel. Biomass Bioenergy, 35, 346-353, 2011.

[9] Unoh, K E. "Performance Evaluation of Modified Sawdust Stove" Project work, Mechanical engineering, University of Agriculture, Makurdi. 2005.

[10] Nicholas, Akhaze Musa Determination of Chemical Compositions, Heating Value and Theoretical Parameters of Composite Agricultural Waste Briquettes, International Journal of Scientific \& Engineering Research Volume 3, Issue 6, June 2012.

[11] Permchart, W., and Tanatvanit, S. "Preliminary investigation on combustion characteristics of rice husk in FBC". World Academy of Science, Engineering and Technology. 56, 2009, p.183186, 2009.

[12] Nasrin, A. B., Choo, Y. M., Lim, W. S., Joseph, L, Michael, S., Rohaya, M. H., Astimar and, A. A. and Loh, S. K. "Briquetting of empty fruit bunch, fibre and palm shell as a renewable energy fuel". Journal of Engineering and Applied Sciences 6(6), pp 446-451, 2011.

[13] Oladeji, J. T."Fuel characterisation of briquettes produced from corn cob and rice husk residues". The pacific Journal of Science and Technology. Vol. 11, No 1, pp.101106, 2010. 